\title{
PTK2 wt Allele
}

National Cancer Institute

\section{Source}

National Cancer Institute. PTK2 wt Allele. NCI Thesaurus. Code C51103.

Human PT K2 wild-type allele is located within 8q24-qter and is approximately $343 \mathrm{~kb}$ in length. This allele, which encodes focal adhesion kinase 1 protein, plays a role in the transduction of adhesion-dependent signals and is involved in adhesion-dependent cell survival signaling. The PTK2 gene is overexpressed in a number of types of cancer such as breast, cervical, colorectal, ovarian, prostate, and thyroid cancers. 